\title{
Retraction Note to: Management of pituitary adenoma with mass effect in pregnancy: a case report
}

U V Okafor ${ }^{1 *}$, I O Onwuekwe ${ }^{2}$ and H U Ezegwui ${ }^{3}$

\section{Retraction note}

This article [1] has been retracted by the publisher because it was republished in the journal [2] due to an error during transfer of the journal between publishers in 2009. BioMed Central apologizes to the authors and readers for this error and for any inconvenience caused.

\footnotetext{
Author details

'Department of Anaesthesia, University Of Nigeria Teaching Hospital (Unth), Enugu, Nigeria. ${ }^{2}$ Department of Internal Medicine, University Of Nigeria Teaching Hospital, Ituku Ozalla, Enugu, Nigeria. ${ }^{3}$ Department of Obstetrics and Gynaecology, University of Nigeria teaching Hospital, Ituku Ozalla, Enugu, Nigeria.
}

\section{References}

1. Okafor UV, Onwuekwe IO, Ezegwui HU. Management of pituitary adenoma with mass effect in pregnancy: a case report. Cases J. 2009;2:9117.

2. Okafor UV, Onwuekwe IO, Ezegwui HU. Management of pituitary adenoma with mass effect in pregnancy: a case report. Cases J. 2009;2:6350.

\footnotetext{
*Correspondence: uvkafor@yahoo.com

${ }^{1}$ Department of Anaesthesia, University Of Nigeria Teaching Hospital (Unth), Enugu, Nigeria

Full list of author information is available at the end of the article
} 